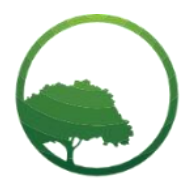

Research in Business \& Social Science

IJRBS VOL 10 NO 4 ISSN: 2147-4478

\title{
Black consumers perceptions towards luxury brands in South Africa
}

(iD) K.Mercy Makhitha

Professor,Department of Marketing and Retail Management, Unisa, South Africa

\author{
ARTICLE INFO \\ Article history: \\ Received 04 April 2021 \\ Received in rev. form 13 May 2021 \\ Accepted 17 May 2021 \\ Keywords: \\ Luxury Brands, Black Consumers, \\ Uniqueness, Rarity, Functional Value, \\ Financial Value \\ JEL Classification: \\ $\mathrm{O} 15$
}

\begin{abstract}
A B S T R A C T
The paper determines the black consumers' perceptions towards luxury brands in South Africa. The purchase of luxury brands has been on the rise locally and internationally. Global brands have been investing in SA by expanding to the region. The demand for luxury brands has also increased over the past decades. In SA, the middle-class group has also increased, particularly the black middle class which increased the market for luxury brands. To achieve the objectives of the study, a survey was conducted among black consumers in Thohoyandou, Venda, South Africa. Data were collected by two fieldworkers who intercepted shoppers visiting a regional mall in the area. Data were analyzed using SPSS 25. The descriptives, factor analysis, and ANOVA were analyzed to achieve the objectives of the study. The findings of the study reveal that black consumers are more influenced by the rarity and uniqueness of the brands followed by the financial and functional values of the brands. Black consumers' perceptions towards luxury brands were found to differ across age and income groups but did not differ across gender and education levels. Organizations targeting black consumers must design brands that are rare and unique and ensure that brands deliver the financial and functional values desired by black consumers.
\end{abstract}

(C) 2021 by the authors. Licensee SSBFNET, Istanbul, Turkey. This article is an open access article distributed under the terms and conditions of the Creative Commons Attribution (CC BY) license (http://creativecommons.org/licenses/by/4.0/).

\section{Introduction}

The luxury market in SA has flourished in the past years as a result of the influx of luxury goods that created an opportunity for emerging market consumers to luxury brands (Bills, 2017:8). The number of millionaires in Africa has also been rising at a faster rate than in the rest of the world, which has resulted in the growing number of consumers buying luxury goods and services (Lodestar Marketing Research, 2015:4). As companies seek opportunities to grow their business, the emerging market has become the destination for luxury brands. The emerging market in Africa has become the destination for Global luxury brands seeking the survival and growth of global luxury brands (Truong et al. 2010). The growing middle class in emerging markets has presented the opportunity for increased spending and consumption (Deloitte, 2017:4). The growth in the luxury market implies that retailers of luxury brands should understand why consumers buy luxury brands and formulate the appropriate marketing strategies to target luxury market consumers. This is especially the case with emerging markets comprising of majority where brands were designed and positioned with high-income consumers in mind.

There has been an increasing number of affluent consumers in emerging economies. These consumers have developed the desire to purchase luxury (Lee, 2016:11). The retail value of the global luxury market was estimated at US\$227.5 billion) in 2010 and was projected to reach as much as US\$252.6 billion in 2011. The luxury market in the emerging markets of Asia Pacific, Latin America, the Middle East and Africa accounted for a combined 19 percent of the global luxury goods market in 2013 and is projected to 25 percent in 2025. Sub-Saharan Africa is second only to Asia Pacific in terms of the size of growth of consumer markets (Deloitte, 2016:1). Since 1994, SA has seen an increase in the middle income as well as high income consumers. This was due to the economic reforms that took place in the country since 1994. The global luxury brands such as Louis Vuitton, Armani, Burberry, Prada, Chanel, Christian Dior, Calvin Klein, and Michael Kors are seen in some major chopping centres in SA. This is an indication that SA consumers are buying luxury brands. With $60 \%$ of Africa's millionaires in South Africa, South Africa is an already established luxury market with infrastructure and quality shopping centers and is considered a destination of choice for many luxury retailers (Lee, 2016:11). According to Lodestar Marketing Research, (2015: 4), the South African market "outperformed expectations" for

* Corresponding author. ORCID ID: 0000-0001-5040-3826

(C) 2021 by the authors. Hosting by SSBFNET. Peer review under responsibility of Center for Strategic Studies in Business and Finance. https://doi.org/10.20525/ijrbs.v10i4.1135 
personal luxury goods like designer apparel, handbags and accessories, fine jewellery and watches, and cosmetics and fragrances. The country holds the sixth spot in the world in terms of the number of shopping centres with most luxury retailers housed in two major shopping malls, namely Sandton City in Johannesburg and V\&A Waterfront in Cape Town (Lee, 2016:11; Lodestar Marketing Research, 2015:5). It is therefore important to determine why consumers in SA, buy luxury products. Black consumers in SA allocate a significant share of their limited income to buying luxury products that do not effectively alleviate poverty or increase their wellbeing (Madyibi, 2017:2). This was supported by Moav and Neeman (2010:414) who argued that poor households often spend their limited income on purchasing visible expensive goods in order to appear more affluent than their poor counterparts. Visible consumption belongs to the realm of conspicuous consumption (Kaus, 2013: 63), which is involves buying higher priced products to inflate one's ego (Truong, 2010:4). A study by Kaus (2013:68) found that African consumers spent more on luxury products than their white counterparts. According to Madyibi, 2017:82) black consumers spend a little less than R1 500 of their realised income on visible consumption, which represents roughly less than $50 \%$ of African households' income spent on luxury product purchase.

A study on luxury consumption by Moroccan consumers reported that the higher income is associated with high probability to purchase luxury goods (Hamelin \&Thaichon, 2016). The black middle class increased to 4.2-million people in 2015 from 1.7-million in 2004 (Steyn, 2013:1). Black consumers in SA are known to prefer luxury brands and buy the luxury products for status (Steinfield, 2015:28) and to display flamboyance and to symbolise success and accomplishments (Atwal \& Bryson, 2014). owever, studies on black consumers' purchase of luxury brands are limited (Atwal \& Bryson, 2013; Steinfield, 2015).

The black consumers are spending money on luxury items and branded goods, especially clothing with their new accumulated wealth and higher paying professional positions they were now able to (Kaus, 2013:70). It is therefore important to determine black consumer's perceptions of luxury products in SA. This is important for retailers who plan to enter or expand in the SA luxury market. The objectives of this study are therefore to:

- Determine black consumer perceptions of luxury products in SA.

- To determine if black consumer perception differ across demographic groups (Age, gender, income and education).

\section{Literature Review}

\section{Theoretical and Conceptual Background}

\section{Defining luxury products}

KPMG (2015:2) defined Luxury goods as products and services not essential to basic needs, for which demand rises more than proportionally than a rise in income. Luxury brands were also defined by Hagtveded and Patrick (2009) as premium products that provide pleasure as a central benefit, and connect with consumers on an emotional level. They further highlighted that luxury brands are bought to delight consumers and not merely to satisfy them. Luxury goods are bought with the primary aim to satisfy an appetite for symbolic meanings. They are sensitive to social influence and are bought as a display of wealth and are the most visible, and include clothing and accessories, automobiles, stereos and furniture (Peshkona, 2013:8). Luxury consumption has its roots in the classic concept of 'conspicuous consumption', which sums up the proposition that the rich tend to consume highly conspicuous goods in order to display their wealth and gain social status (Truong, 2010:4). Conspicuous consumption involves buying a higher priced product to inflate one's ego, a desire for status involves buying something that represents status to both the individual and to surrounding significant others (Eastman, Goldsmith \& Flynn (1999:43). According to Athwal, Wells, Carrigan, \& Henninger. 2019:1), luxury is synonymous with superior quality, uniqueness and going beyond need and is extravagant in terms of effort and material. However, the recent 'massification' of luxury has offered entry-level products and services (Kapferer 2017) which meant that more and more consumers are able to purchase luxury products. Whilst decades ago saw organisations selling, luxury goods purchase targeted at high net worth consumers and in established market, organisations are increasingly reaching middle-income consumers in emerging markets.

KPMG (2015:2) identified the global luxury products as consisting various market segments: personal luxury goods such as accessories, apparel, jewellery, and cosmetics, high-end vehicles, luxury hospitality, cruises, custom furniture, fine food, wines, champagne $\&$ spirits, yachts and private aviation. Luxury products are products are not essential for daily life but products that people buy to satisfy their status needs. The type of luxury products bought may depend on the luxury segment. For example, Stiehler (2017) investigated the luxury products purchase in SA and identified four groups of luxury market segments: Deluxe aspirers, Money aristocracy, Self-made and Business magnate. The market segments differ depending on the purpose of purchasing luxury products since some buy for everyday use while others buy for special occasion. They also differ on the amount of wealth they pose and the products they can afford to buy (Stiehler, 2017:22).

\section{Black consumers perception of luxury goods}

Studies on black consumer behavior towards luxury products stated that black consumers buy luxury products to express their desire for more possessions to affirm their social status and newfound place in society. This is because they were previously deprived and were unable to access or purchase luxurious or status products (Chipp, Kleyn \& Manzi, 2011:131). Scheepers (2016:73) studied perceptions of female consumers in SA and found that social value perceptions, functional perceptions, individual gifts perceptions 
and financial perceptions influence their intention to purchase luxury products. However, the functional value perceptions had more influence than others. Black consumers are influenced by value expressiveness, utilitarian influence and high self-monitoring (Cronje, Jacobs \& Retief, 2016: 8). According to Amatulli and Guido (2012:203) luxury brands are evaluated based on different dimensions: ostentation, materials, superfluousness, individual lifestyle, emotions and culture. However, existing studies identified various other dimensions used to evaluate luxury brands. The dimensions include materialism, hedonism, face saving and social connections (Chen \& Kim, 2013:38) other dimension identified by Chen \& Kim (2013) are confucian, collectivism, individual or group needs, values of being modest and thrifty. Face saving was defined by Goffman, (1967:5) as "the positive social value a person effectively claims for himself by the line others assume he has taken during a particular contact," The symbolic and social values associated with luxury consumption may vary across culture (Wang, Sun \& Song, 2011). Other studies also found different factors influencing luxury brands purchase as shown in the below table. Furthermore, studies also found that factors influencing luxury brands purchase differ for different consumers. For example, Wang et al., (2011:352) identified three groups of luxury brands buyers such as elitists, democratic and distant buyers and that these consumers use different factors to evaluate luxury brands. Stiehler (2017:102) found the opportunistic luxury market and that this market possesses the least luxury knowledge. According to Stiehler (2017:102) luxurious in their countries of origin are entering the South African market at substantially higher prices, thereby creating the perception of being luxury brands. This has made luxury brands more accessible in the country.

Table 1: Factors influencing luxury product purchase

\begin{tabular}{|c|c|c|}
\hline Authors & Country & Factors \\
\hline Cronje et al., 2016 & SA & Value expressiveness, utilitarian and high-self monitoring \\
\hline $\begin{array}{l}\text { de Barnier \& } \\
\text { Rodina (2004) }\end{array}$ & Russia & $\begin{array}{l}\text { Aesthetics, premium quality, personal history, functionality, self-pressure, uniqueness, } \\
\text { expensiveness }\end{array}$ \\
\hline Berthon et al. (2009) & $\begin{array}{l}\text { Conceptual } \\
\text { paper: no } \\
\text { country } \\
\text { identified }\end{array}$ & $\begin{array}{l}\text { Functional: product quality, experiential: personal hedonic nature and symbolic: } \\
\text { conspicuous to others and enhances the consumer's concept of self) }\end{array}$ \\
\hline Dubois et al. (2001) & France & $\begin{array}{l}\text { Excellent quality, high price, scarcity and uniqueness, aesthetics and polysensuality, } \\
\text { ancestral heritage and personal history, and superfluousness. }\end{array}$ \\
\hline $\begin{array}{l}\text { Hamelin \& Thaichon, } \\
(2016: 168)\end{array}$ & Morocco & Conspicuousness, uniqueness, price, brand name and service. \\
\hline Hennigs et al., (2015) & Germany & Social value, functional value, financial value and individual value \\
\hline Scheepers (2016:73) & SA & Social value, functional value, individual gifts and financial value \\
\hline Stiehler, (2017) & SA & $\begin{array}{l}\text { Status, image, functional designs, lasting properties and high quality, self-gifts and } \\
\text { rewards for hard work, functional comfortable designs, uniqueness and style. }\end{array}$ \\
\hline Truong et al., (2008) & France & $\begin{array}{l}\text { Status: status-laden brands may be purchased for internal reasons (self-reward) or external } \\
\text { reasons (signal wealth) } \\
\text { Conspicuous brands: purchased for purely external reasons that is for systematic public } \\
\text { display in order to signal wealth }\end{array}$ \\
\hline $\begin{array}{l}\text { Vel and Rodrigues } \\
(2013: 885)\end{array}$ & UAE & $\begin{array}{l}\text { Personal characteristics: Culture, Service, website quality, consumer satisfaction. } \\
\text { Vendor characteristics: demographics, external environment, and product Characteristics }\end{array}$ \\
\hline Wang, et al., (2011:352) & China & $\begin{array}{l}\text { Self-actualization, social comparison, others' influence, investment for future, buying for } \\
\text { special time, and buying out of emotions. }\end{array}$ \\
\hline
\end{tabular}

From the above discussions, it is clear that factors influencing consumers to purchase luxury brands vary according to the country and the type of luxury products being bought. It is there important to determine the factors influencing consumers in SA to purchase luxury brands. Although studies on luxury brands purchase have been conducted in SA, they focused on young consumers, affluent consumers and very few on the black middle-class consumers in SA.

\section{Empirical Review}

Luxury brand purchase and gender

Scheepers (2016) suggested female consumers do not have intention to purchase luxury products. It was further reported that the African consumers in SA are driven to use luxury goods to display flamboyance and to symbolise success and accomplishments, which is shared with others (Atwal \& Bryson, 2014). However, Cronje et al (2016) found that luxury brands purchase behaviour of black consumers does not differ across gender of consumers. This shows that there are contradicting findings with regard to the effect of gender on luxury brands purchase since Roux a , Tafani \& Vigneron (2017:108) also found that gender influence luxury brands purchase and that male and females consumers consider different factors when purchasing luxury brands. It is therefore hypothesised that:

$H_{I}$ : There is statistically significant differences among different gender of the respondents when purchasing luxury brands. 
Luxury brand purchase and age

A study on young consumers' behaviour towards luxury products found luxury consumption across social class- high-income, the middle- and low-income classes (Dubihlela \& Dubihlela 2017:134). These findings differ from those of Cronje et al (2016) that reported that luxury does not differ across age groups. However, Alvandi, Fazli \& Najafi (2013:963) support that factors influencing luxury brands purchase differ across age groups with teens emphasizing different factors than other consumer groups when purchasing luxury brands. It is evident from these findings that age does influence luxury brands purchase, although this differs across types of consumers and regions where consumers are located. It is therefore hypothesized that:

$H_{l}$ : There is statistically significant differences among different age groups of the respondents when purchasing luxury brands.

Luxury brand purchase and education level

The consumer's willingness to pay high prices for luxury brands was fund by Li, Li and Kambele (2012:1521) to differ across the level of education of consumers. The following hypothesis was therefore formulated as follows:

H3: There is statistically significant difference among different gender of the respondents when purchasing luxury brands.

Luxury brand purchase and income

The buyer behavior of consumers towards luxury brands differ across the level of income they receive. For example, Wand, Sun \& Song (2011:355) found that luxury consumers across luxury brands segments spend differently towards luxury brands due to the differences in come they possess. Cronje et al (2016) support that the purchase behavior of black consumers' differs across income group and that marketers should emphasize different factors when targeting consumers of different income segments. Against the above discussions, the following hypothesis was formulated:

H4: There is statistically significant difference among different gender of the respondents when purchasing luxury brands.

\section{Research and Methodology}

\section{Study design}

A survey research method was deemed appropriate in order to achieve the objectives of this study. Prior studies on luxury brands adopted a survey method to determine the behaviour and attitude of consumers towards luxury brands (Chen \& Kim, 2013; Wang et al., 2011 and Truong, et al., (2008). A survey requires a respondent to choose a response from those provided and allows a researcher to compare responses (Babbie \& Mouton, 2001:233). It was appropriate for this research to determine the perceptions black consumers have towards luxury brands.

\section{Sample design}

Black consumers living in Thohoyandou, Venda, were targeted for this study with the purpose to determine their perception towards luxury product brands. The sample population for the study was retail consumers who shop at Thavhani mall in Thoyandou Venda, SA. Thavhani mall is the only regional mall in Venda, which opned in 2017. . The population in Thohoyandou in South Africa consists of both rural and urban consumers. The mall is closer to Khoroni hotel, one of the biggest hotel in Venda and also closer to the University of Venda. Thavhani mall has over a million people visiting the mall since its establishment in August 2017. The convenience sampling was used. Convenience sampling offers benefits to researchers, such as that it gives the researcher or fieldworker freedom to choose whom they find and it is cheaper and easier to conduct (Cooper \& Schindler, 2006:216).

\section{Questionnaire construction}

The questionnaire was developed using the scales of prior research studies: personnel (Hamelin \& Thaichon, 2016; Wang et al., 2013, Chen \& Kim, 2013). Eight demographic questions were included in the questionnaire. In addition, 22 statements of the questionnaire covered statements needed to determine consumer perceptions of luxury brands. The shoppers were asked to rate each of the luxury brands on a Likert scale from 1 to 5, with 1 measuring "strongly disagree" and 5 measuring "strongly agree".

\section{Data collection and data analysis}

Data were collected from March to April 2019 by two fieldworkers. Consumers shopping a Thavhani mall were targeted. Field workers were trained to approach shoppers and ask them for permission to participate in the study. There were no incentives offered to the shoppers. A questionnaire consisted of 22 statements measuring consumer attitude towards luxury brands. 300 questionnaires were printed for the study. However, 250 usable questionnaires were completed. Questionnaires that were incomplete were discarded. Fieldworkers intercepted consumers at the mall and permission was granted by mall management. The data were analysed with the aid of IBM SPSS for Windows, version 25. Various statistical analyses were conducted to achieve the objectives of this study, including descriptive analyses, such as mean and standard deviation, factor analysis, ANOVA and regression analysis

\section{Results and findings}

The results and findings will be discussed here. The demographics and findings from the statistical analysis will be presented here. 
Table 2: Demographics of the respondents

\begin{tabular}{|c|c|c|c|}
\hline & & Frequency & Percentage \% \\
\hline \multirow[t]{7}{*}{ Age } & $18-24$ years & 84 & $37.67 \%$ \\
\hline & $25-29$ years & 60 & $26.91 \%$ \\
\hline & $30-40$ years & 51 & $22.87 \%$ \\
\hline & 41-50 years & 14 & $6.28 \%$ \\
\hline & $51-60$ years & 11 & $4.93 \%$ \\
\hline & $60+$ years & 3 & $1.35 \%$ \\
\hline & TOTAL & 223 & $100 \%$ \\
\hline \multirow[t]{3}{*}{ Gender } & Male & 125 & $59.24 \%$ \\
\hline & Female & 86 & $40.76 \%$ \\
\hline & TOTAL & 211 & $100 \%$ \\
\hline \multirow[t]{3}{*}{ Marital status } & Married & 50 & $22.83 \%$ \\
\hline & Unmarried & 169 & $77.17 \%$ \\
\hline & TOTAL & 219 & $100 \%$ \\
\hline \multirow[t]{7}{*}{ Monthly Income } & $0-\mathrm{R} 2500$ & 102 & $45.95 \%$ \\
\hline & R2501 - R5000 & 39 & $17.57 \%$ \\
\hline & R5000 - R7500 & 20 & $9.01 \%$ \\
\hline & R7500 - R12 500 & 11 & $4.95 \%$ \\
\hline & R12 500 - R20 000 & 30 & $13.51 \%$ \\
\hline & Over R20 000 & 20 & $9.01 \%$ \\
\hline & TOTAL & 222 & $100 \%$ \\
\hline \multirow[t]{6}{*}{ Highest Qualification } & Did not complete high school & 12 & $5.41 \%$ \\
\hline & Completed grade $12 /$ matric & 65 & $29.28 \%$ \\
\hline & Post school qualification - diploma/certificate & 62 & $27.93 \%$ \\
\hline & Post school qualification - degree & 73 & $32.88 \%$ \\
\hline & Completed short courses & 10 & $4.50 \%$ \\
\hline & TOTAL & 222 & $100 \%$ \\
\hline
\end{tabular}

As shown in Table 2 above, majority of respondents were in the age group 18-24 ( $\mathrm{n}=84,37.67 \%$ ) followed by age group $25-29$ ( $\mathrm{n}=84$, $26.91 \%)$ and $30-40$ years $(n=51,22.87 \%)$. there were more as shown by $59 \%$ of respondents and $41 \%$ of females $(n=86)$. The married respondents constituted $23 \%$ of the respondents while the unmarried respondents were in majority (77\%, $\mathrm{n}=169)$. Respondents earning an income of up to R2500 represented 46\% ( $n=102)$ of tall the respondents followed by those earning R2500 - R5000 ( $n=39)$ and R12500 to R20 $000(n=30)$. The respondents whose income is R2500 to over R20 000 are represented by $23 \%$ of the population. Respondents with a degree and diploma represented $33 \%(n=73)$ and $28 \%(n=62)$ of the population respectively. The respondents with matric were represented by $29 \%$ of the population $(n=65)$. Most of the respondents shop only when needed $(n=66, n=29 \%)$ followed by those who shop monthly $(n=53,24 \%)$. Majority of respondents commute by taxi $(n=97,43 \%)$ followed by those with own transport $(\mathrm{n}=57,25 \%)$.

\section{Validity and reliability}

To test the validity of all the constructs (dimensions/factors) in the questionnaire, an exploratory factor analysis is performed to determine if the individual questions load (or contribute) onto the constructs as intended in the questionnaire. The questionnaire was designed using the scales of prior research studies to satisfy content validity. Furthermore, to determine the validity of the instrument, the threshold of 0.26 to 0.63 was maintained on the communalities. The questionnaire was also pre-tested and approved by two academics. Several minor modifications of the wording and the question item sequence were done based on the comments of the two academics. Cronbach's alpha was employed to test instrument reliability. The reliability analysis yielded an overall Cronbach's alpha of 0.90 for the five supermarket attributes. The individual Cronbach's alpha of each factor was between 0.55 and 0.80 , which shows reliability across attributes studied in this research. According to Malhotra (2010), a Cronbach's alpha coefficient of less than 0.50 is deemed unacceptable; those between 0.50 and 0.69 are considered adequate, whereas those above 0.70 are regarded as acceptable.

\section{Factor analysis}

Exploratory Factor analysis was applied to responses of the 22 -item "Perceptions towards luxury clothing brands" scale in the questionnaire. Principal Axis Factoring was used to extract the factors, and this was followed by a quartimin (oblique) rotation. Only the first six factors exhibited Eigenvalues greater than or near 1; results of a scree plot also suggested that only the first six were meaningful. Therefore, only the first six factors were retained for rotation. Combined, the first six factors accounted for $61 \%$ of the total variance. Scale items and corresponding factor loadings are presented in Table 3. Using these criteria, five items were found to 
load on the first factor, which was subsequently labelled "Uniqueness". Three items loaded on the second factor, labelled "Gift", three items loaded on the third factor, labelled "Financial value", four items loaded on the fourth factor, labelled "Functional value", three items loaded on the fifth factor, labelled "Rarity" and only two items loaded on the sixth factor labelled "Status".

Table 3: Factor analysis

\begin{tabular}{|c|c|c|c|c|c|c|}
\hline & $\begin{array}{l}\text { Factor } 1 \\
\text { Uniqueness }\end{array}$ & $\begin{array}{l}\text { Factor } \\
\text { 2: Gift }\end{array}$ & $\begin{array}{l}\text { Factor } 3 \\
\text { Financial }\end{array}$ & $\begin{array}{l}\text { Factor } 4 \\
\text { Functional }\end{array}$ & $\begin{array}{l}\text { Factor } 5 \\
\text { Rarity }\end{array}$ & $\begin{array}{l}\text { Factor } 6 \\
\text { Status }\end{array}$ \\
\hline $\begin{array}{l}\text { People who buy luxury clothing brands have a } \\
\text { refined taste }\end{array}$ & 0.60 & -0.07 & 0.17 & 0.27 & 0.02 & -0.21 \\
\hline $\begin{array}{l}\text { People who buy luxury clothing brands try } \\
\text { to differentiate themselves from others }\end{array}$ & 0.58 & 0.10 & -0.05 & -0.02 & 0.14 & 0.03 \\
\hline $\begin{array}{l}\text { One buys luxury clothing brands primarily } \\
\text { for one's pleasure }\end{array}$ & 0.56 & -0.01 & -0.03 & -0.00 & 0.25 & 0.04 \\
\hline $\begin{array}{l}\text { The luxury clothing brands we buy reveal a } \\
\text { little bit who we are }\end{array}$ & 0.54 & -0.02 & -0.04 & 0.01 & 0.27 & 0.01 \\
\hline $\begin{array}{l}\text { In my opinion, luxury clothing brand is } \\
\text { flashy }\end{array}$ & 0.53 & 0.11 & 0.11 & -0.05 & -0.23 & 0.09 \\
\hline $\begin{array}{l}\text { I would not feel at ease in a luxury clothing } \\
\text { shop }\end{array}$ & -0.03 & 0.67 & 0.00 & 0.11 & 0.08 & -0.09 \\
\hline I'm not interested in luxury clothing brands & 0.11 & 0.55 & 0.05 & -0.14 & -0.06 & 0.04 \\
\hline $\begin{array}{l}\text { For the most part, luxury clothing brands are } \\
\text { to be offered as gifts }\end{array}$ & 0.15 & 0.47 & 0.00 & 0.12 & 0.26 & 0.09 \\
\hline $\begin{array}{l}\text { I do not know much about the luxury clothing } \\
\text { brands }\end{array}$ & 0.07 & 0.34 & -0.03 & -0.09 & -0.05 & 0.29 \\
\hline Luxury clothing brands are worth the money & 0.01 & -0.15 & 0.62 & 0.10 & 0.08 & 0.09 \\
\hline $\begin{array}{l}\text { In my opinion, luxury clothing brands are } \\
\text { pleasant }\end{array}$ & 0.14 & -0.08 & 0.62 & 0.05 & 0.13 & -0.04 \\
\hline $\begin{array}{l}\text { Luxury clothing brands should be taxed } \\
\text { more heavily }\end{array}$ & -0.09 & 0.31 & 0.54 & -0.03 & -0.07 & -0.03 \\
\hline $\begin{array}{l}\text { I don't think luxury clothing brand is } \\
\text { important }\end{array}$ & 0.19 & 0.20 & 0.28 & -0.46 & -0.04 & 0.08 \\
\hline $\begin{array}{l}\text { Luxury clothing brands make life more } \\
\text { beautiful }\end{array}$ & 0.11 & 0.23 & 0.20 & 0.61 & -0.02 & 0.09 \\
\hline $\begin{array}{l}\text { In my opinion, luxury clothing brand is good } \\
\text { taste }\end{array}$ & 0.13 & 0.14 & 0.27 & 0.51 & 0.05 & 0.10 \\
\hline $\begin{array}{l}\text { All things considered, I rather like luxury } \\
\text { clothing brands }\end{array}$ & 0.34 & -0.02 & 0.19 & 0.50 & -0.15 & 0.15 \\
\hline $\begin{array}{l}\text { Truly luxury clothing brands cannot be mass } \\
\text { produced }\end{array}$ & 0.12 & 0.22 & -0.02 & 0.06 & 0.59 & 0.02 \\
\hline $\begin{array}{l}\text { A luxury clothing brand cannot be sold in } \\
\text { supermarkets }\end{array}$ & 0.04 & -0.11 & 0.16 & -0.05 & 0.51 & 0.15 \\
\hline $\begin{array}{l}\text { Few people own a truly luxury clothing } \\
\text { brand }\end{array}$ & 0.19 & 0.26 & 0.05 & -0.08 & 0.44 & 0.09 \\
\hline Luxury clothing brands are expensive & -0.02 & -0.09 & -0.03 & -0.03 & 0.04 & 0.60 \\
\hline $\begin{array}{l}\text { In general, luxury clothing brands are better } \\
\text { quality }\end{array}$ & -0.11 & -0.00 & 0.22 & 0.26 & 0.10 & $\mathbf{0 . 5 0}$ \\
\hline $\begin{array}{l}\text { A real luxury clothing brand does not } \\
\text { advertise its products }\end{array}$ & 0.16 & 0.24 & -0.12 & 0.15 & 0.13 & 0.36 \\
\hline Eigen value & 5.883 & 2.115 & 1.691 & 1.512 & 1.620 & 1.036 \\
\hline Cumulative percentage & 26.74 & 36.36 & 44.04 & 50.92 & 56.91 & 6.136 \\
\hline$\%$ of variance & 3.743 & 2.487 & 2.573 & 1.914 & 2.174 & 1.986 \\
\hline $\mathbf{M}$ & 3.59 & 3.49 & 3.80 & 3.49 & 3.10 & \\
\hline
\end{tabular}

Estimates of internal consistency as measured by Cronbach's alpha coefficient were all acceptable and good except for Status. A score will not be calculated for Status and it will not be used in further analysis. From the above table, consumers perceive rarity $(\mathrm{M}=3.80)$ to have more influence towards purchase of luxury brands followed by uniqueness of the brand (M=3.59). These findings are in consonant with those from previous studies that found uniqueness to influence luxury brands purchase (Scheepers, 2016:79). 
Consumers prefer uniqueness and rarity of the brands because they want to differentiate themselves from others in the society with a unique fashion sense (Chan, NG, Lim \& Chen, 2017:14). The financial and functional values scored equally with a mean score of 3.59 each. Previous studies on luxury brand purchase found functional and financial values to have more influence towards luxury brands purchase (Scheepers, 2016:66). Hennings et al (2015:932) also found financial and functional values to influence luxury brands purchase. According to Shukla (2012:592) functional value perceptions are significantly important to consumers in developed markets. these consumers are increasingly seeking to purchase unique products which have high price quality perceptions.This implies that the value attached to luxury brands differs across consumers' types and regions from where consumers are located. Shukla (2012:593) also reported status to have significant influence on luxury brands purchase across both developed and emerging markets provides managers with an opportunity to standardize their campaigns

\section{Discussion}

\section{The Demographic Influence towards Luxury Brand Purchase}

A one-way ANOVA was conducted to examine whether there were statistically significant differences among different levels of the biographical variables' management in relation to the constructs of the scale. A one-way ANOVA was conducted to examine whether there were statistically significant differences among different gender of the respondents. The results revealed that there is no statistically significant difference between the different gender groups.

A one-way ANOVA was conducted to examine whether there were statistically significant differences among different age groups in relation to their mean Uniqueness scores. The results revealed statistically significant differences between the different Age groups, $(\mathrm{F}(4,220)=4.07, \mathrm{p}=0.0034)$ the effect size was determined by the Eta square of 0.07 referring to a medium size effect. Post-hoc Tukey-Kramer's HSD t tests revealed a statistically significant difference $(\mathrm{p}=0.0080)$ between the 18-24 years $(\mathrm{M}=3.39)$ and $41-50$ years $(\mathrm{M}=4.07)$. The Cohen's D of 0.97 relates to a large effect. A study by Dubihlela and Dubihlela (2017:134) confirmed that young South Africans from all the social structures attach significance to prestige, snobby and materialistic consumption of status brands. Stiehler (2017:132) also reported that luxury brands purchase differs across age group with those in the younger age groups more inclined to purchase luxury brands. Furthermore, the Moroccan youth were found to be more willing to buy luxury products than its elders. Income was also found to have positive influence towards purchase of luxury goods (Hamelin \& Thaichon, 2016:168). A one-way ANOVA was conducted to examine whether there were statistically significant differences among different education level of the respondents. The results revealed that there are no statistically significant differences between the different education levels. A one-way ANOVA was conducted to examine whether there were statistically significant differences among different income groups in relation to their mean Uniqueness scores. The results revealed statistically significant differences between the different income groups, $(\mathrm{F}(5,220)=3.56, \mathrm{p}=0.0041)$ the effect size was determined by the Eta square of 0.07 referring to a medium size effect. Post-hoc Tukey-Kramer's HSD t tests revealed a statistically significant difference ( $\mathrm{p}=0.0055)$ between the R2501-R5000 (M $=3.88)$ and over R20 $000(\mathrm{M}=4.83)$. The Cohen's D of 0.68 relates to a large effect.

\section{Conclusions}

This study found that functional value $(M=3.80)$ and uniqueness $(M=3.59)$ are two main factors influencing consumer's perceptions towards purchase luxury brands in SA. The functional value and gift were also important with mean scores of 3.49 each. Rarity was considered less important with a Mean score of 3.10. Therefore markets of luxury brands must ensure that their brands are unique and differentiating them from other brands in the market. Marketers must ensure that luxury brands are sold in specialty or boutique stores so as to retain the uniqueness of the brands. Marketers must satisfy consumer's functional and financial values of the brands, and ensure that the prices charged for the brands communicate the uniqueness and functional values of the brands. This requires that markers formulate a comprehensive marketing strategy for luxury brands with specific focus on the benefits of the dimensions of luxury brands. The Anova tests found no significant differences among gender. This means that marketers can market luxury brands using similar strategies across consumers of different gender. The study also found no significant differences among consumers of different education level, which means that education had no influence towards luxury brands purchase. Judging by the income groups of respondents, consumers in SA purchase luxury brands despite their income. This could be because some retailers such as Edgars and Spitz, for example, sell luxury brands through store cards which makes it affordable by consumers. Retailers could also expand the market by introducing entry level luxury brands by introducing accessories and adapted brands while maintaining the quality of the brand. They could also provide product ranges that can also be afforded by consumer of different income groups without compromising on the value and quality of the brands. For example, car manufactures such as BMW and Audi introduced small versions of their brands to ensure that consumers who likes their brands and cannot afford the bigger versions can afford their brands by purchasing the smaller models.

Further, the results of the study showed that luxury brands purchase differ across age groups of consumers. Marketer should therefore use different marketing strategies when targeting consumers of different age groups. Consumers between the age of 18-25 and those between 40 were more influenced by the uniqueness of the brands than other consumers. Consumers of different income groups were also found to differ on the factors influencing luxury brands purchase. Those earning the R2501-R5000 (M =3.88) and over R20 000 $(M=4.83)$ emphasize uniqueness of the brands than other consumer groups. Since perceptions towards luxury brands purchase differ 
across age and income level of consumers, marketers must base their marketing strategies on the factors important to consumers to improve purchase value for different segments of luxury consumers, who may differ in their value.

In conclusion, consumers in SA buy luxury products regardless of their income status. This study found that functional values are more important for consumers when purchasing luxury brands followed by uniqueness and financial values and gift which were equally important. This is an indication that black consumers prefer brands that distinguish them from the majority of consumers in the market. Rarity as a factor was rated less than other factors could mean that black consumers they prefer brands are financially accessible but still unique. The perception towards luxury brands were also found to differ across age groups and income groups but did not differ across gender and education levels of consumers. Young consumers were found to purchase luxury brands than the older group. The study targeted consumers in Venda, Limpopo. Therefore there results cannot be generalized to consumers in SA. Other studies can investigate consumers across regions in SA. Future studies could also investigate the types of brands that black consumers across income groups purchase. Furthermore, studies could identify other factors influencing black consumer luxury brands purchase.

\section{References}

Albeck, W., Huth, S. \& Braun, M. (2014). Winning poor consumers in Africa: Best practises from mobile network operators. International Journal of Business and Emerging Markets, 6(4):340-355.

Alvandi, M., Fazli, S \& Najafi, S. (2013). Investigating the impact of self on attitudes toward luxury brands among teens in Iran International Research Journal of Applied and Basic Sciences, 5 (7): 854-865.

Amatulli, C \& Guido, G. (2012). Externalised vs. internalised consumption of luxury goods: propositions and implications for luxury retail marketing, The International Review of Retail, Distribution and Consumer Research, 22:2, 189-207.

Athwal, N., Wells, V.K., Carrigan, M \& Claudia E. Henninger, C.E. (2019). Sustainable Luxury Marketing: A Synthesis and Research Agenda. International Journal of Management Reviews, 00:1-22.

Atwal, G. \& Bryson, D. (2013). The luxury market in Africa - emerging consumer empowerment is creating a luxurious future. [Online] Available at: theafricanbusinessreview.com/wp...TABR_Dec_2013_20-22_HQ.pdf [Accessed 6 July 2014].

Berthon, P., Pitt, L., Parent, M \& Berthon, J. (2009). Aesthetics and Ephemerality: observing and preserving the luxury brand. California Management, 52(1):45-66.

Bills, A. (2017). Luxury Brands in the South African Emerging Market: An empirical study of the relationship between consumer personality traits and purchase intentions towards luxury brands. Dissertation: Vega School.

Busitech. (2019). This is how many South Africans are worth more than R420 million

https://businesstech.co.za/news/wealth/303894/this-is-how-many-south-africans-are-worth-more-than-r420-million/.

Cham, T.H., Ng, C.K.Y., Lim, Y.M \& Cheng, B.L.( 2019). Factors Influencing Clothing Interest and Purchase Intention: A Study of Generation Y Consumers in Malaysia. The International Review of Retail, Distribution and Consumer Research.

Chen, J \& Kim, S. (2013). A Comparison of Chinese Consumers' Intentions to Purchase Luxury Fashion Brands for Self-Use and for Gifts. Journal of International Consumer Marketing, 25:29-44.

Chipp, K., Kleyn, N \& Manzi, T. (2011). Catch Up and Keep Up: Relative Deprivation and Conspicuous Consumption in an Emerging Market. Journal of International Consumer Marketing, 23(2):117-134.

Cooper, D.R. \& Schindler, P.S. (2006). Business Research Methods. $9^{\text {th }}$ Edition. McGraw-Hill.

Cronje, A., Jacobs, B \& Retief, A. (2016). Black urban consumers' status consumption of clothing brands in the emerging South African market. International Journal of Consumer Studies, (40):754-764.

De Barnier, V \& Rodina, I. (2004). Which luxury perceptions affect most consumer purchase behavior? A cross-cultural exploratory study in France, the United Kingdom and Russia. Unpublished paper. Accessed at, http://archives.marketing-trendscongress.com/2006/Materiali/Paper/Fr/DeBarnier_Rodina_ValetteFlorence.pdf.

Deloitte. (2017). Emerging market insights The coming emerging market demand shock. https://www2.deloitte.com/content/dam/Deloitte/za/Documents/africa/DeloitteZA_Demand_\%20Shock_\%20Sep2017.pdf

Deloitte. (2015). Accessed at https://www2.deloitte.com/za/en/pages/consumer-business/articles/luxury-brands-powers-ofluxury.html.

Deloitte. (2014). Luxury brands turn to Africa as the next growth frontier - Deloitte.

https://www2.deloitte.com/za/en/pages/consumer-business/articles/luxury-brands-powers-of-luxury.html.

Dubihlela, J \& Dubihlela, D. (2017). Young South African Consumers' Conspicuous Consumption Patterns and their Status-BrandShopping Behaviour. J Soc Sci, 53(3): 128-136.

Dubois, B ., Laurent , G . and Czellar, S. (2001). Consumer Rapport to Luxury: Analyzing Complex and Ambivalent Attitudes . HEC, Jouy en Josas, France. Consumer research working paper no. 736.

Eastman, J.K., Goldsmith, R.E \& Flynn, L.R (1999). Status Consumption in Consumer Behavior: Scale Development and Validation, Journal of Marketing Theory and Practice, 7:3, 41-52, DOI: 10.1080/10696679.1999.11501839.

Hagtveded , H \& Patrick , V. (2009) The broad embrace of luxury: Hedonic potential as a driver of brand extendibility . Journal of Consumer Psychology 19 (4) : $608-619$.

Hamelin, N \& Thaichon, P. (2016). Consumer motives and impact of western media on the Moroccan luxury buyer. Journal of Retailing and Consumer Services 32:164-170. 
Hennigs, N., Wiedmann, K., Klarmann, C \& Behrens, S. (2015). The complexity of value in the luxury industry: From consumers' individual value perception to luxury consumption", International Journal of Retail \& Distribution Management, 43(10/11):922-939.

Hing, K., Chen A.H., Peng, N., Rungpaka, H., Tiwsajul, A \& Chou C. (2011). Antecedents of luxury brand purchase intention, Journal of Product \& Brand Management, 20(6): 457 - 467.

Kapferer J.N. (2017). Managing luxury brands. In Kapferer J.N., Kernstock J., Brexendorf T. and Powell S. (eds), Advances in Luxury Brand Management. Cham, Switzerland: Palgrave Macmillan.

Kapferer, J. N. (2012). Abundant rarity: The key to luxury growth. Business Horizons, 55(5), 453-462).

KPMG. (2016). Luxury goods and wealth management in Africa. http://www.blog.kpmgafrica.com/wpcontent/uploads/2017/01/Luxury-Goods-and-Wealth-Management-in-Africa-2016.pdf

KPMG. (2015). Sector report: Luxury Goods in Africa. https://www.africanbusinesscentral.com/wpcontent/uploads/2015/11/Luxury-Goods-in-Africa-A-Maturing-Sector-KPMG.pdf.

Kaus, W. (2013). Conspicuous consumption and "race": Evidence from South Africa. Jrn. of Development Economics 100:63-73.

Lee, L.W. K. (2016) Luxury retail brands and their consumers in emerging markets: developing mobile marketing and sustaining the brand value, Durham theses, Durham University. Available at Durham E-Theses Online: http://etheses.dur.ac.uk/11738/.

Li, G., Li, G \& Kambele, Z. (2012). Luxury fashion brand consumers in China: Perceived value, fashion lifestyle, and willingness to pay. Journal of Business Research, 65: 1516-1522.

Lodestar Marketing Research. (2015). The luxury fashion industry in South Africa. Switzerland Global Enterprise. http://www.iberglobal.com/files/2016-2/sudafrica_luxury_fashion_swiss.pdf.

Madyibi, S. (2017). The Relationship between Conspicuous Consumption and Poverty in Developing Countries: Evidence from South Africa. Thesis: University of Western Cape.

Peshkova, A. (2013). Symbolic consumption of luxury goods: example of fashion luxury market in Russia. Dissertation: University of Kassel.

Rice, X. (2013). Africa's Wealthy Revel in Luxury Labels. Accessed at: http://www.ft.com/cms/s/0/e61f123c-8713-11e2-bde600144feabdc0.html\#axzz2RfXKKcpW.

Roux, E., Tafani, E \& Vigneron, F. (2017). Values associated with luxury brand consumption and the role of gender. Journal of Business Research, 71: 102-113.

Scheepers, S. (2017). Luxury value perceptions that drove South Africa female consumers purchase intent for luxury exotic leather accessories. Dissertation: University of Pretoria.

Shukla, P. (2012). The influence of value perceptions on luxury purchase intentions in developedand emerging markets", International Marketing Review, 29(6):574-596.

Steinfield, L. (2015). Consumer Types versus Stereotypes: Exploring Social Tensions in the Luxury Market of South Africa. Saïd Business School Research $\quad$ Papers. Accessed at file:///C:/Users/makhikm/Downloads/Steinfield2015ConsumerTypesversusStereotypesExploringSocialTensionsintheLuxuryMarketofSouthAfrica.pdf.

Stiehler, B.E. (2017). Identification and assessment of luxury brand segments in the emerging markets: Case of South Africa. Doctoral Thesis: KTH Royal Institute of Technology, Division of Industrial Marketing, INDEK, Stockholm, Sweden.

Stiehler B., Lee L.W. (2016) Luxury Branding in Emerging Markets. In: Obal M., Krey N., Bushardt C. (eds) Let's Get Engaged! Crossing the Threshold of Marketing's Engagement Era. Developments in Marketing Science: Proceedings of the Academy of Marketing Science. https://link.springer.com/chapter/10.1007/978-3-319-11815-4_25.

Steyn, L. (2013) The black-belt economy kicks in. Mail \& Guardian. [WWW document]. URL http://mg.co.za/article/2013-05-0300-the-black-belt-economy-kicks-in. Accessed 19 September 2019.

Truong, Y. (2010). Personal aspirations and the consumption of luxury goods. International Jrn.of Market Research, 52(5):655-673.

Truong, Y., Simmons, G., McColl, R \& Kitchen, P.J. (2008). Status and Conspicuousness - Are They Related? Strategic Marketing Implications for Luxury Brands. Journal of Strategic Marketing, 16:3, 189-203.

Tynan, C. , McKechnie , S . and Chhuon , C . (2010). Co-creating value for luxury brands. Jrn. of Business Research 63 (11):11561263.

Vel, P \& Rodrigues, J. (2013). Online Purchase of luxury products in the U.A.E. World Academy of Science, Engineering and Technology. International Journal of Social, Human Science and Engineering 7(7):

Wang, Y., Sun S \& Song, Y. (2011). Chinese Luxury Consumers: Motivation, attitude and behavior, Journal of Promotion Management, 17:3, 345-359.

Publisher's Note: SSBFNET stays neutral with regard to jurisdictional claims in published maps and institutional affiliations.

\section{(a) (1)}

(C) 2021 by the authors. Licensee SSBFNET, Istanbul, Turkey. This article is an open access article distributed under the terms and conditions of the Creative Commons Attribution (CC BY) license (http://creativecommons.org/licenses/by/4.0/).

International Journal of Research in Business and Social Science (2147-4478) by SSBFNET is licensed under a Creative Commons Attribution 4.0 International License. 